\section{AL-AZHAR}

Assiut Dental Journal
The Official Publication of The

Faculty of Dental medicine.

Al-Azhar Assiut Uniuersity.

AADJ, Vol. 2, No. 2, October (2019) - PP. 101:107

ISSn 2682-2822

\title{
Evaluation of Dexamethasone Injection into the Pterygomandibular Space in Impacted Lower Third Molar Surgery
}

\author{
Ahmed E.W. El Dakroury ${ }^{* 1}$, Ahmed A.H. Elfekey ${ }^{1}$, Mansour M. Hussien ${ }^{1}$
}

Codex : 12/1910

Aadj@azhar.edu.eg

\section{KEYWORDS}

Keywords: Dexamethasone, Pterygomandibular, Impacted

Lower 3rd molar Surgery,

Interincisal Distance, VAS.

1. Department of Oral and Maxillofacial Surgery, Faculty of Dental Medicine, Al-Azhar University, (Cairo, boys), Egypt.

* Corresponding Author e-mail: ahmedwahba.p.9@azhar.edu.eg

\begin{abstract}
Aim: It was to evaluate the efficacy of dexamethasone (Dx) of a single dose of 8 $\mathrm{mg}$ dexamethasone injected pre-operatively into the pterygomandibular space in reducing post-operative pain, swelling, and limited mouth opening following lower third molar surgery. Subjects and Methods: A prospective, randomized, split mouth study involving 62 surgical extractions of lower third molars in 31 patients. range $(20-35$ years) with similar bilaterally impacted lower third molars. Sites from the study group (SG) received single dose of $2 \mathrm{ml}$ of $4 \mathrm{mg}$ Dx preoperatively, while those in the control group (CG) received a placebo (the same volume of sterile saline solution). Previous history of significant medical condition, drug allergy, or infection that may contraindicates the use of Dx was excluded. Results: Significant reduction in swelling, pain and total postoperative analgesic consumption was observed in SG than CG on the 2nd day. Also, there were differences between both groups regarding to the interincisal distance (IID) measurements on the 7th day. Conclusion: Both groups showed acceptable results, however, Dx injection seems to be the appropriate treatment for rapid recovery of range of IID, reduction of swelling, and relief of pain following impacted lower $3^{\text {rd }}$ molar extraction.
\end{abstract}

\section{INTRODUCTION}

Surgical extraction of the lower $3^{\text {rd }}$ molar is one of the most performed procedures. It may occur unilateral or bilateral. ${ }^{(1)}$ Postoperative trismus, swelling, and pain are related to that procedure. They vary according to the degree of tissue trauma, and the extent of bone manipulation. ${ }^{(2)}$ Numerous strategies arouse to limit the postoperative sequelae in order to increase the patient's comfort, by inhibiting the synthesis or the release of the inflammatory mediators, including different closure techniques, drains, physical methods as cryotherapy and laser application, and drugs comprising analgesics and corticosteroids (CS)..$^{(3,4)}$ 
CS are potent inhibitors of inflammation, used in different regimens. ${ }^{(5)}$ The start of CS in dental field began in 1950s, when Spies et al. ${ }^{(6)}$ administered hydrocortisone to prevent inflammation in oral surgery. Today, there is consensus that regaining pain free function after lower $3^{\text {rd }}$ molar surgery is an essential element, so Dx has been introduced due to its pure glucocorticoid effects, no mineralocorticoid effects, and the least effects on leukocyte chemotaxis. ${ }^{(7)}$ Many studies, ${ }^{(8-13)}$ reported submucosal, intraalveolar, intravenous, intramuscular and oral use of CS. Injection of CS into Pm is preferred in decreasing trismus, swelling, and pain at the operative site, reducing the postoperative discomfort, and confirm the effectiveness of locally administered CS in $3^{\text {rd }}$ molar surgery. ${ }^{(14)}$

The aim of this study was to evaluate the clinical results and to examine prospectively if there is an improved outcome in patients injected with a single dose of $8 \mathrm{mg}$ Dx into the Pm. To receive comparable results, classification of impacted molars and inclusion criteria were defined.

\section{PATIENTS AND METHODS}

\section{Eligibility Criteria}

The study design involved healthy patients (2035 years) with bilateral lower $3^{\text {rd }}$ molars with similar degree of impaction, indicated for surgical extraction, and good oral hygiene. All patients were analyzed with orthopantomograms (OPGs).

Patients were not admitted into the study if any of the following exclusion criteria were present: Previous significant medical history, infection, drug allergy, chronic use of medication that may contraindicate the use of Dx, pregnant or medically compromised, unlikely to attend all the visits, mental incapacity that prevented obtaining informed consent, and legal incompetence.

\section{Settings, Interventions, Follow up}

The patients were selected from the Outpatient Clinic of the Departments of Oral and Maxillofacial Surgery at Faculty of Dental Medicine, Al-Azhar University (Boys' branch), Cairo and El-Sayed Jalal Hospital, Cairo, Egypt, during the period from May 2016 to December 2018. It is a double blinded split mouth study where operative sites were divided randomly and equally into SG and CG. In order to reduce postoperative sequlae after surgery, SG was injected preoperatively by a single dose of $2 \mathrm{ml}$ of $4 \mathrm{mg}$ (8 mg) Dx into Pm (Figure 1), after inferior alveolar, lingual and long buccal nerve block, while CG was injected by a placebo (sterile saline solution of the same volume) with the same technique.

Altogether, 62 extraction sites in this study, of which 31 were assigned to $S G$ and 31 to $C G$, were actively under FU 2 and 7 days after surgery. The subjective assessment of complaints was collected which included personal history, medical and dental history, and clinical investigation of the surgical area. An informed consent was obtained before commencement of the treatment after explaining the study design and procedures. The local ethics review committee of the Faculty of Dental Medicine for Boys at Al-Azhar University approved the study.

\section{Study measurements}

They include the IID by vernier caliper, the facial swelling by flexible tape, the pain by using VAS, and the amount of analgesics consumed postoperatively.

\section{Operative Phase}

The same surgeon performed all the operations under aseptic standard technique, disinfection of the operation field was achieved with Betadine, under local anathesia via standard inferior alveolar, lingual, and long buccal nerve block using a solution of 4\% articaine hydrochloride with 1:100,000 epinephrine, then $2 \mathrm{ml}$ of Dx (4 mg/ml, total $8 \mathrm{mg}$ ) was injected into the $\mathrm{Pm}$ by the same technique 
of inferior alveolar nerve block using a $3 \mathrm{ml}$ Luertip syringe (22-gauge), a standard pyramidal flap was performed to access the site via blade no.15, mounted on B.P scalpel handle no.3. Buccal and distal guttering was done to facilitate delivery of the third molar using a surgical round bur. If necessary, sectioning of crown and roots was done with a fissure bur and tooth delivery. The socket was irrigated with copious sterile saline solution, hemostasis was achieved and the flap was sutured by interrupted sutures with (3-0) vicryl.

\section{Postoperative Phase:}

After surgery, a small gauze pack was applied to the surgical site, and the patient was requested to hold it firmly for about 1 hour. Patients received instructions regarding local haemostatic measures, feeding, cleaning of the operated region, restriction of physical exertion, and other routine postoperative recommendations. The patients were noted to take antibiotics (amoxicillin with clavulanic acid, $1 \mathrm{gm}$ oral tablets twice for five days or for patients allergic to penicillin, erythromycin $500 \mathrm{mg} 3$ times), and analgesics as (voltaren 50mg tablets), immediately following surgery and twice for a maximum of 3 days, and chlorhexidine mouthwash were prescribed for 5 days. Patients were advised to record pain intensity and amount of analgesic tablets consumed. The intraoral sutures were removed after 7 days.

\section{Statistical Analysis}

Data were tabulated and the statistical measurements were obtained using statistical software IBM SPSS 22.0 for Windows software.

\section{RESULTS}

\section{Demographic Data:}

There were no clinically differences between the 2 groups. The mean patient age was $27 \pm 7$ years in both groups. 11 male and 20 female $(\mathrm{P}=1)$.
Outcomes: In regard to the IID, there were no significant differences between the 2 groups at baseline (pre), however, at 2nd day; there was a statistically significant difference $(\mathrm{P}=0.007)$, on the $7^{\text {th }}$ day, there was no statistically significant difference between IID measurements in the 2 groups, but SG showed a higher mean of IID (Table1).

Table(1): Comparison between the two groups according to the interincisal distance.

\begin{tabular}{|c|c|c|c|c|c|c|}
\hline \multirow{2}{*}{} & \multicolumn{2}{|c|}{ Study } & \multicolumn{2}{c|}{ Control } & \multirow{2}{*}{ t } & \multirow{2}{*}{ p } \\
\cline { 2 - 5 } & Mean & \pm SD & Mean & \pm SD & & \\
\hline Maximum mouth opening $(\mathbf{m m})$ \\
\hline Pre & 44.61 & 9.93 & 42.80 & 9.50 & 0.417 & 0.682 \\
\hline $2^{\text {nd }}$ day & 38.28 & 10.24 & 30.67 & 8.48 & 1.810 & $0.007^{*}$ \\
\hline $7^{\text {th }}$ day & 42.63 & 9.62 & 37.05 & 9.48 & 1.306 & 0.208 \\
\hline
\end{tabular}

\section{t: Student t-test}

$p: p$ value for comparing between two studied groups

At base line (pre) and at 7th day; there was no statistically significant difference between maximum mouth opening measurements in the two groups.

In relation to facial swelling, at base line (pre) and at 7 th day; there was no statistically significant difference between facial swelling measurements in the 2 groups. While, at 2 nd day; there was a statistically significant difference $(\mathrm{P}<0.05)$. SG showed reduction in the mean of facial swelling measurements (Table 2).

Table(2): Comparison between the two groups according to facial swelling measurements.

\begin{tabular}{|c|c|c|c|c|c|c|}
\hline \multirow{2}{*}{$\begin{array}{l}\text { Assessment of } \\
\text { facial swelling } \\
(\text { edema })(\mathrm{cm})\end{array}$} & \multicolumn{2}{|c|}{ Study } & \multicolumn{2}{|c|}{ Control } & \multirow{2}{*}{$\mathbf{t}$} & \multirow{2}{*}{$\mathbf{p}$} \\
\hline & Mean & \pm SD & Mean & \pm SD & & \\
\hline \multicolumn{7}{|c|}{ Eye angle of mandible } \\
\hline Pre & 10.50 & 1.84 & 10.65 & 1.70 & 0.189 & 0.852 \\
\hline $2^{\text {nd }}$ day & 12.45 & 1.86 & 14.30 & 1.99 & $2.147^{*}$ & $0.046^{*}$ \\
\hline $7^{\text {th }}$ day & 10.65 & 1.80 & 12.15 & 1.72 & 1.909 & 0.072 \\
\hline
\end{tabular}




\begin{tabular}{|c|c|c|c|c|c|c|}
\hline \multirow{2}{*}{$\begin{array}{l}\text { Assessment of } \\
\text { facial swelling } \\
(\text { edema })(\mathrm{cm})\end{array}$} & \multicolumn{2}{|c|}{ Study } & \multicolumn{2}{|c|}{ Control } & \multirow{2}{*}{$\mathbf{t}$} & \multirow{2}{*}{$\mathbf{p}$} \\
\hline & Mean & \pm SD & Mean & $\pm \mathrm{SD}$ & & \\
\hline \multicolumn{7}{|c|}{ Tragus - corner of mouth } \\
\hline Pre & 12.20 & 1.89 & 12.80 & 2.04 & 0.682 & 0.504 \\
\hline $2^{\text {nd }}$ day & 14.0 & 2.36 & 16.45 & 3.02 & $2.021^{*}$ & $0.048^{*}$ \\
\hline $7^{\text {th }}$ day & 12.25 & 1.78 & 14.10 & 2.46 & 1.926 & 0.070 \\
\hline \multicolumn{7}{|c|}{ Tragus -soft tissue pogonion } \\
\hline Pre & 15.40 & 2.22 & 15.45 & 2.31 & 0.049 & 0.961 \\
\hline $2^{\text {nd }}$ day & 17.45 & 2.54 & 19.95 & 3.24 & $1.921^{*}$ & $0.041^{*}$ \\
\hline $7^{\text {th }}$ day & 15.30 & 1.93 & 16.60 & 2.34 & 1.354 & 0.193 \\
\hline
\end{tabular}

\section{t: Student t-test}

$p: p$ value for comparing between two studied groups

*: Statistically significant at $p \leq 0.05$

After revising the amount of analgesics consumed within the first 3 consecutive days, it was observed that, at all periods; there was a statistically significant difference between the amounts of analgesic measurements in the 2 groups. In addition SG showed a lower mean of analgesic consumption (Table 3).

Table(3): Comparison between the two groups according to amount of analgesics consumed.

\begin{tabular}{|l|c|c|c|c|c|c|}
\hline & \multicolumn{2}{|c|}{ Study } & \multicolumn{2}{c|}{ Control } & \multirow{2}{*}{ U } & \multirow{2}{*}{ p } \\
\cline { 2 - 5 } & Mean & \pm SD & Mean & \pm SD & & \\
\hline Number of analgesic \\
\hline Day1 & 1.70 & 0.48 & 2.70 & 0.48 & $10.5^{*}$ & $0.002^{*}$ \\
\hline Day2 & 2.10 & 0.32 & 3.10 & 0.88 & $18.0^{*}$ & $0.015^{*}$ \\
\hline Day3 & 1.30 & 0.48 & 2.40 & 0.52 & $9.0^{*}$ & $0.001^{*}$ \\
\hline
\end{tabular}

\section{U: Mann Whitney test}

$p: p$ value for comparing between two studied groups

*: Statistically significant at $p \leq 0.05$

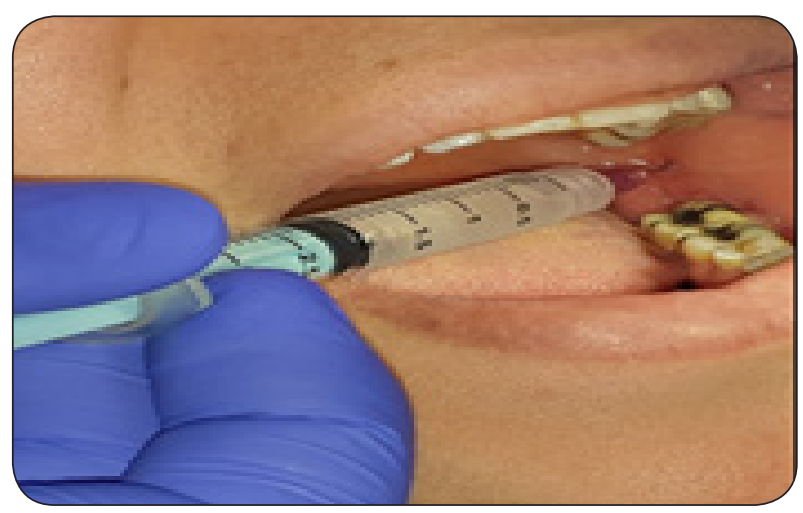

Fig. (1) Photographs showing Preoperative Injection of $2 \mathrm{ml}$ Dx in Pm (SG).

\section{DISCUSSION}

Lower $3^{\text {rd }}$ molars are of clinical concern, from the moment they are formed until they are removed. They account for $98 \%$ of all impactions, as they are the last teeth to erupt. Their management is a complicated operation involving soft tissue, muscle and bone. The access site is highly vascular and constantly flooded with saliva. Trismus, edema, and pain are normal sequlae of third molar surgery; Therefore CS was used for their anti-inflammatory, and analgesic effects to reduce these consequences. $(\mathbf{1 5 , 1 6 )}$ The main results of this study supported this suggestion, were the injection of a single dose of $8 \mathrm{mg}$ Dx into Pm, immediately before surgical removal of lower $3^{\text {rd }}$ molar in SG enabled them to regain IID, prevent edema, and reduce pain in agreement with Boonsiriseth. ${ }^{(14)}$

Dx is an ideal synthetic glucocorticoid drug with biological half-life from 36-54 h, 20-30 times more potent than cortisol, it has no mineralocorticoid activity, it maintains a high therapeutic plasma level through the early postoperative period, and it shows a faster cell membrane penetration. ${ }^{(17)}$ The PtS was chosen for Dx injection as it is adjacent to the surgical site, and contains mostly loose areolar tissue with a rich vascular supply, which helps in faster drug absorption. The injection technique was similar to inferior alveolar nerve block, which is familiar to dental practitioners. ${ }^{(18)}$ A dose of $8 \mathrm{mg}$ Dx 
was administered preoperatively to obtain the best results, to achieve adequate tissue level, and less systemic absorption as recommended by other studies. ${ }^{(17,19)}$ On the contrary, other authors advocated postoperative administration. ${ }^{(20,21)}$

The ID was regained in SG at the $2^{\text {nd }}$ day, who also attained better results on the $7^{\text {th }}$ day in consistent with different studies. ${ }^{(22,23)}$ The facial swelling was measured by flexible tape to achieve accurate measurements to the convex profile of the face as it is valid, easy to use, and cheap method. ${ }^{(24)}$ The SG showed a lower mean facial swelling at the $2^{\text {nd }}$ day as reported by Filho et al. ${ }^{(25)}$ The mean of VAS pain scores was lower in the SG at postoperative evaluation that lead to less consumption of amount of analgesics in agreement with multiple studies. ${ }^{(23,26)}$

The key findings of this study are that injection of a single dose of $8 \mathrm{mg}$ Dx into the Pm is a convenient method with high successful rate and low cost. Also, Dx provided a shortened period of discomfort, when compared to placebo. The clinical importance is that Dx prevents the risk of trismus.

\section{REFERENCES}

1. Brunello G, De Biagi M, Crepaldi G, Rodrigues FI, Sivolella S. An Observational Cohort Study on delayedonset Infections after mandibular third-molar extractions. Int j dent. 2017; 2017.

2. Sabhlok S, Kenjale P, Mony D, Khatri I, Kumar P. Randomized controlled trial to evaluate the efficacy of oral dexamethasone and intramuscular dexamethasone in mandibular third molar surgeries. J clin diag res. 2015; 9: 48.

3. Zandi M, Amini P, Keshavarz A. Effectiveness of cold therapy in reducing pain, trismus, and oedema after impacted mandibular third molar surgery: a randomized, selfcontrolled, observer-blind, split-mouth clinical trial. Int $\mathrm{j}$ oral maxillofac surg. 2016; 45: 118-23.

4. Osunde O, Adebola R, Omeje U. Management of inflammatory complications in third molar surgery: a review of the literature. Afric health sci. 2011; 11: 3.

5. Nandini G. Eventuality of dexamethasone injected intramassetrically on postoperative sequel following the sur- gical extraction of impacted mandibular third molars:A prospective study.J maxillofac oral surg. 2016;15: 456-60.

6. Spies TD, Dreizen S, Stone RE, Garcia-Lopez G, LopezToca R, Reboredo A. A clinical appraisal of ACTH and cortisone as therapeutic agents in dental medicine. Oral Surg, Oral Med, Oral Path. 1952; 5: 25-40.

7. Hafez AG, Elsharrawy EA, Abdelmabood AA. Comparative study between methylprednisolone and dexamethasone as submucosal injection for control of edema, trismus and pain of third molar surgery. Bas Res J Med Clin Sci. 2014; 3: 55-61.

8. Kan E, Coelho MS, Reside J, Card SJ, Tawil PZ. Periapical Microsurgery: The effects of locally injected dexamethasone on pain, swelling, bruising, and wound Healing. J endo. 2016; 42: 1608-12.

9. Shirani M, Hasanzade M, Moadabi A, Attar BM. Comparison of the effectiveness of dexamethasone injection into two different sites in preventing the postoperative complications after mandibular third molar surgery: A Randomized Clinical Trial. Br J Med Med Res. 2016; 13: $1-11$.

10. Chen Q, Chen J, Hu B, Feng G, Song J. Submucosal injection of dexamethasone reduces postoperative discomfort after third-molar extraction: A systematic review and meta-analysis. J Am Dent Assoc 2017; 148: 81-91.

11. Kumar HH. Comparison of intravenous and submucosal dexamethasone on postoperative sequale following third molar surgery. . J Adva Med Dent Sci Res. 2017; 5: 20.

12. Lima CAA, Favarini VT, Torres AM, da Silva RA, Sato FRL. Oral dexamethasone decreases postoperative pain, swelling, and trismus more than diclofenac following third molar removal: a randomized controlled clinical trial. Oral Maxillofa Surg. 2017: 1-6.

13. Gozali P, Boonsiriseth K, Kiattavornchareon S, Khanijou $\mathrm{M}$, Wongsirichat N. Decreased post-operative pain using a sublingual injection of dexamethasone $(8 \mathrm{mg})$ in lower third molar surgery. J Dent Anesth Pain Med. 2017; 17: 47-53.

14. Boonsiriseth K, Latt MM, Kiattavorncharoen S, Pairuchvej $\mathrm{V}$, Wongsirichat N. Dexamethasone injection into the pterygomandibular space in lower third molar surgery. Int. J. Oral Maxillofac. Surg. 2017; 46: 899-904.

15. Majid OW, Mahmood WK. Use of dexamethasone to minimise post-operative sequelae after third molar surgery: comparison of five different routes of administration. Oral Surg 2013; 6:200-8. 
16. Gersema L, Baker K. Use of corticosteroids in oral surgery. Journal of oral and maxillofacial surgery. 1992; 50: 270-7.

17. Bhargava D, Sreekumar K, Deshpande A. Effects of intraspace injection of Twin mix versus intraoral-submucosal, intramuscular, intravenous and per-oral administration of dexamethasone on post-operative sequelae after mandibular impacted third molar surgery: a preliminary clinical comparative study. Oral Maxillofacial Surg 2014;18: 293-6.

18. Lipski M, Lipska W, Motyl S et al. Anatomy of the pterygomandibular space - clinical implication and review. Folia Med Cracov 201;53:79-85

19. Alcântara C, Falci S, Oliveira-Ferreira F, Santos C, Pinheiro M. Pre-emptive effect of dexamethasone and methylprednisolone on pain, swelling, and trismus after third molar surgery: A split-mouth randomized triple-blind clinical trial. Int J Oral Maxillofac Surg 2014;43:93-8.

20. Dereci O, Tuzuner-Oncul AM, Kocer G, Yuce E, Askar M, Ozturk A. Efficacy of immediate postoperative intramasseteric dexamethasone injection on postoperative swelling after mandibular impacted third molar surgery: A preliminary split-mouth study. J Pak Med Ass. 2016; 66: 320-3.

21. Rocha-Neto AM, de Carvalho Nogueira EF, Borba PM, Laureano-Filho JR, do Egito Vasconcelos BC. Application of dexamethasone in the masseter muscle during the surgical removal of lower third molars. J Cranfac Surg. 2017; 28: e43-e7.

22. Antunes AA, Avelar RL, Martins Neto EC, Frota R, Dias E. Effect of two routes of administration of dexamethasone on pain, edema, and trismus in impacted lower third molar surgery. Oral Maxillofac Surg 2011; 15:217-23.

23. De Oliveira GS, Almeida GS, Honorio T, Benzon HT, McCarthy RJ. Perioperative single dose systemic dexamethasone for postoperative pain. Anesthesiology 2011; 115: 575-88.

24. Gabka J, Matsumura T. Measuring techniques and clinical testing of an anti-inflammatory agent (tantum). Munchener medizinische Wochenschrift (1950). 1971; 113: 198.

25. Filho JR, Maurette PE, Allais M, Cotinho M, Fernandes C. Clinical comparative study of the effectiveness of two dosages of dexa- methasone to control postoperative clinical swelling, trismus and pain after the surgical extraction of mandibular impacted third molars. Med Oral Patol Oral Cir Bucal 2008;13:E129-32.

26. Barbalho J, Vasconcellos R, de Morais H, Santos L, de AC Almeida R, Rêbelo H, Lucena E, de Araújo S. Effects of co-administered dexamethasone and nimesulide on pain, swelling, and trismus following third molar surgery: a randomized, triple-blind, controlled clinical trial. Int J Oral Maxillofac Surg. 2017; 46: 236-42. 


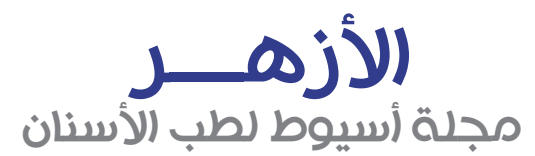

النشر الرسمي لكلية طب الأسنان

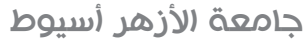

\title{
تقييم حقن عقار الديكساميثازون في منطقه الحئراميز الجناحي

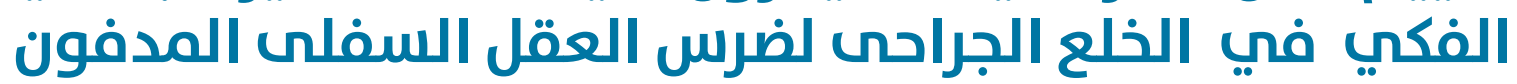

\author{
احمد السيد وهبـه الدكرورى*, احمد حسين الفقى , منصور محمد حسين \\ قسهم جراحة الفم والوجه وافكين، كلية طب الاسنان، جامعة الازهر، ( القاهره، بنين )، مصر \\ AHMEDWAHBA.P.9@AZHAR.EDU.EG : البريد الالكترونى *
}

الملخص :

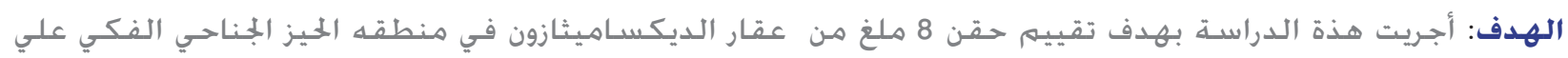

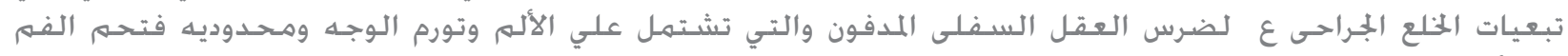

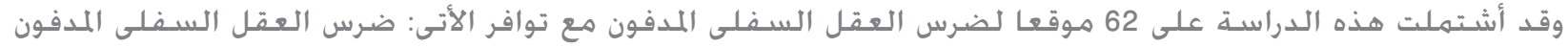

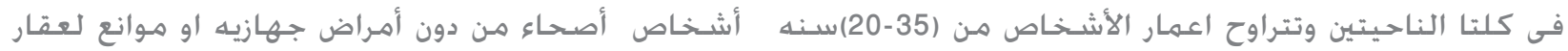
الديكساميثازون

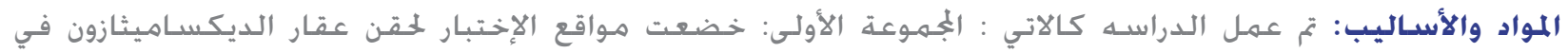

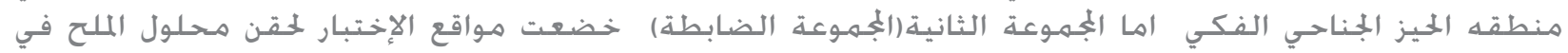
منطقه الحيز الجناحي الفكيز الجني الفيكي

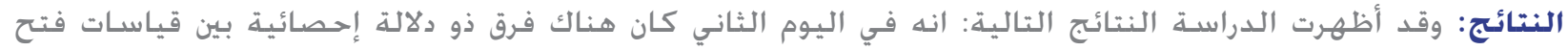

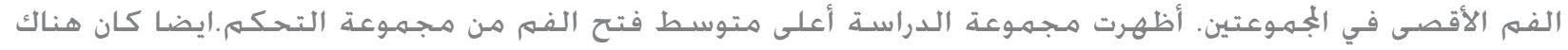

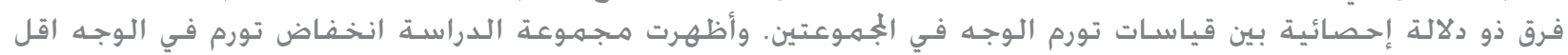

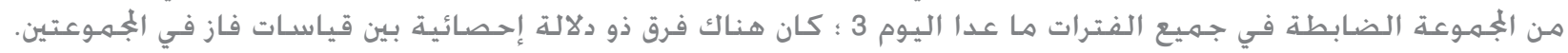

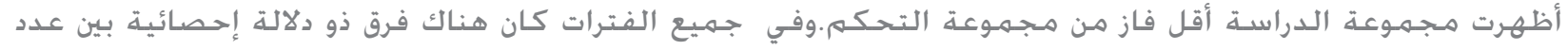

المسكنات في الجمهوعتين.

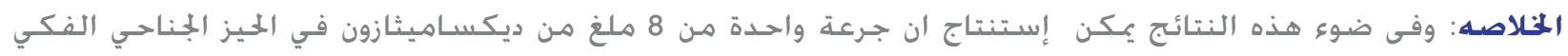

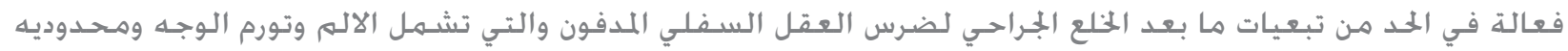
فتحهم الفم.

الكلمات المفتاحيه: ديكساميثازون, حيز الجناحي الفكي, تثبيت, الخلع الجمراحي لضرس العقل السفلي المدفون ,المسافهـ

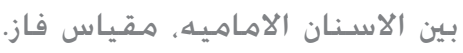

